\title{
Tax Competition - Beneficial or Harmful? How Various Tax Measures Affect the Allocation of Resources?
}

\author{
Adina Violeta Trandafir, "Spiru Haret” University, Constanta
}

\begin{abstract}
Fiscal competition has been in the news ever since the OECD launched a campaign against "harmful tax competition" in 1996. Nor is it likely to disappear any time soon. Instead, it is likely to intensify, as more and more governments resort to lower taxes to stimulate their economies. Is all tax competition harmful, or is it possible to distinguish between harmful and beneficial tax competition? In this paper, in its first part, I try to present the difference between benefit and harmful tax competition. Also, the paper try to establish how really is tax competition - "harmful" or "beneficial". The second parts of this paper analyze the impact and efficiency of different tax measures in allocation of public resources.
\end{abstract}

\section{Keywords}

tax competition, tax measures, allocation of resources, harmful tax competition

JEL Code: $H 20$

\section{Tax Competition Between Beneficial and Harmful}

Competition is universally hailed as a "good thing". It is recognized as being socially superior to its opposite, namely a monopoly or a cartel. The reason is very simple: where there is competition, even among the few, the individual customer or small firm is much better treated. The scope for exploitation disappears. The competing firm must innovate, watch its cost structures, seek to please its market, and sell at market prices which it cannot raise without running the risk of seeing its customers shift to its competitors. A monopoly or cartel does none of these things. It exploits its customers and suppliers, does not care about costs, does not innovate, and prices its product to maximize its own utility function. The rents it extracts from its privileged position are usually dissipated in high salaries, long holidays and short working hours for its employees.

Anyone arguing against competition must bear the burden of proof, for the general presumption is heavily in favor. Turning now to fiscal competition in particular, is this not also presumably a "good thing", for the very same reasons that competition in general is to be preferred to monopoly? Fiscal competition is merely a special case of the more general phenomenon of institutional or regulatory competition, which both an Austrian like F.A. Hayek $^{1}$ and a neo-classical economist like Douglass C. North ${ }^{2}$ have described as being a process whereby "better" institutions (from a utilitarian standpoint) gradually replace worse ones. Thus fiscal competition could be expected to yield both lower taxes and more care in controlling the costs of raising them, greater attention would be paid to the rational management of public expenditure, and possibly even some institutional and regulatory

${ }^{1}$ HAYEK, F.A., The Constitution of Liberty, The University of Chicago Press, Chicago, 1960, especially Chapter 3 "The Common Sense of Progress", pp.39-53.

${ }^{2}$ NORTH, Douglass C., Structure and Change in Economic History,, Norton \& Co. New York \& London, 1981. 
innovation might occur. The tax-payer could expect to get better value in terms of public goods, per unit of tax effort, and he would enjoy more freedom to spend his own money as he pleases.

A fiscal monopoly, on the other hand, would tend to exploit its tax payers to the hilt, waste their money, and meet every financial shortfall with higher taxes rather than lower expenditure, for this would be the easy way out, and there would be no restraining influence on its actions.

To the extent that government is not all-wise and benevolent, but rather subject to capture by and of special interest groups, many of the conventional arguments in favor of optimal public goods provision by the State fall by the wayside, for we learn that the State will tend to maximise, rather than optimise its role If so, the case in favor of fiscal competition is stronger than ever.

What, then, might be its drawbacks? In an increasingly open world economy, where investments flow easily from one country to another, one country's tax system may have a negative impact on another's, and vice versa. One obvious negative spill-over effect might occur when a tax-induced misallocation of resources spills over onto a neighbouring country through unfair competition in trade and investment. However, tax induced misallocations which have no negative external effects must surely be permitted, since other countries have no right to interfere in another country's sovereign affairs. A country's own internal misallocations must be considered to be motivated by a public policy agenda which overrides considerations of efficient allocation of resources, and lie within the normal sovereign sphere of action of a modern state. Therefore, a useful guide to distinguishing between beneficial and harmful tax competition would be to distinguish between taxes which cause a clear international misallocation of resources, and which are therefore harmful to others, and those which do not. If fiscal competition were to reinforce harmful tax practices, then it would itself be harmful.

\section{Various Tax Measures and its Efficiency in Allocation of Resources}

\section{Discriminatory Tax Regimes for Favored Industries}

When governments offer special tax regimes to the ship-building industry, or for oil exploration, or for informatics research, they are really offering a subsidy ${ }^{3}$. Such tax privileges distort the allocation of resources and are indeed harmful - harmful to the country engaging in them, harmful to the firms receiving the tax breaks (they are shielded from economic reality, and will in due course wither away precisely because once support is withdrawn, they will fail, whereas if they had been forced to face reality from the start, they might have had at least a chance of long term survival) and ruinous for the exchequer if several governments decide to subsidize the same industry at the same time. Sectorial tax privileges are clearly "harmful" and competition in granting them simply makes things even worse. It is therefore no surprise that the EU and GATT have strict rules and understandings limiting governments' freedom to act in this domain.

\section{Non-Discriminatory Tax Regimes}

While sector-specific tax breaks, discussed above, distort the allocation of resources between sectors and are clearly harmful and banned in both the WTO and the European Union, many governments use the tax code to pursue more general policy objectives, such as investment in general, or, more specifically, foreign direct investment. Clearly, the more "general" a measure, and the less sector-specific it is, the less it distorts the allocation of resources, and the less "harmful" it is in economic terms. Competition between countries on matters of

\footnotetext{
${ }^{3}$ One should not forget that different rates of customs tariffs are also disguised subsidies for particular industries, which in an open world economy could also result in the artificial shifting of investment from one country to another. This form of subsidization and "poaching" other countries' investments is however absent from the OECD's definition of harmful tax practices and will not be further alluded to.
} 
general taxation cannot be "harmful", because it does not lead to an inter-sectoral misallocation of resources with negative international effects. It must therefore benefit from the general presumption in favor of competition outlined above, and be deemed beneficial. A generally favorable attitude to business, for instance, achieved by low taxes and light labour laws, might make a country prosperous, and might even attract investment from high-tax countries, but according to the above rule would not constitute "harmful" tax competition, even if it did appear to be "bidding aggressively for the tax base of other countries" ${ }^{4}$ (one of the OECD's definitions of "harmful tax competition"). A moment's reflection will confirm, however, that this definition of "harmful tax competition" is either wrong and/or inoperative: wrong, because light tax laws are not necessarily harmful, and might be beneficial to some; inoperative, because "bidding aggressively" is in the eye of the beholder and would be stoutly denied, for instance, by a country like Estonia ${ }^{5}$. It is an unscientific and unverifiable criterion.

\section{"Ring-Fenced" Tax Regimes}

Under the heading of "ring fencing" the OECD/EU identify, and condemn as being "harmful", intermediate measures which are neither clearly sector-specific, nor absolutely general. Here, some distortion of resources occurs, and is indeed intended, in the name of public policy objectives of various kinds. By "ring fencing" the OECD/EU mean tax measures which distinguish between various potential tax payers within the same tax jurisdiction, but which are not sector-specific. For example, governments often offer tax inducements to foreign multinational firms, in the hope of attracting them to their shores. These tax privileges are "ring fenced" in that they are not available to local entrepreneurs, in the belief that foreign investments are somehow superior to local investment, or represent net new investment, and therefore need to be encouraged. Sometimes governments further limit such tax privileges to "green-field" foreign direct investment, in the belief that a "new" plant in a greed field is somehow better for the economy than refurbishing an existing plant in an established industrial area (known as a "brown-field" investment). Of course it does not matter which form the investment takes, as long as the existing assets (green or brown fields) are put to more productive use by more imaginative entrepreneurs. However, since the foreign entrepreneurs benefit from a tax privilege compared with local firms, we cannot be sure that this is in fact the case. In the meantime, the assets having been bought up by foreigners, the local sellers must then decide what to do with their money: since all countries offer much the same type of inducements, they will probably look abroad for an equivalent tax deal. Tax competition of this kind causes an over-stimulation of foreign, as opposed to domestic investment and is clearly "harmful" in an economic sense. But does it distort international competition? The answer is yes, but it is a matter of degree, and only a judicial or diplomatic procedure can identify the cases which deserve redress. For example, when the UK succeeds in attracting a major Japanese car manufacturer to Scotland with a tempting tax package, firms trying to make money from automobile production without tax breaks are clearly discriminated against, and may well complain.

International misallocation spill-overs occur within a Single Market like the EU or in global markets under the law of WTO, and give rise to disputes.

This type of competitive behavior is a good example of "bidding aggressively for the tax base of other countries". It is clear that if all governments compete with each other to attract foreign multinationals, resource misallocation will surely occur and much tax payers' money will be wasted. It certainly does not increase employment over-all, even for the country which wins the race, since resources spent attracting foreign investment have to be taken

\footnotetext{
${ }^{4}$ OECD, Harmful Tax Competition: An Emerging Global Issue, Paris, 1998, p. 16.

${ }^{5}$ Estonia is attracting much foreign direct investment, possibly as a consequence of a zero corporate tax rate on retained earnings.
} 
from somewhere else in the economy. Both the OECD and the $\mathrm{EU}^{6}$ have tried their best to outlaw such wasteful measures, which clearly distort markets in their actual application, even if formally they do not favour one sector over another. Channelling foreign direct investment into economically backward regions is generally considered to be acceptable, at least in the EU, and will not be condemned as "illicit state aid" as long as the investment takes place within the designated area and is not "excessive". Such policies find their justification in the notion of market failure, and the need for corrective government intervention. However, the aid must not exceed the failure, for that would constitute a subsidy. A considerable part of the EU budget and manpower is devoted to supervising and enacting the EU's regional policy. While neither the EU nor the OECD classify these policies as "harmful tax competition" they do in fact create a distortion between subsidized and non-subsidized regions of a country, and shift employment and investment from one area to another. However, that is indeed their objective, and as long as the distortion exercises no negative competition externalities on other countries, it may generally be considered as "non-harmful" (but not necessarily beneficial) in terms of our classification system.

\section{Other Forms of "Ring-Fencing"}

Most countries tax their residents on the basis of the "territorial principle": they tax income earned within the country, give tax credits on income earned abroad by their residents and already taxed once by a foreign tax authority, and they tax income earned by non-residents if it arises within their jurisdiction. It is generally agreed that income should not be taxed twice, giving rise to a dense network of double tax agreements which regulate the detailed application of these general rules. The United States is exceptional in that it taxes its citizens wherever they reside, on their world-wide income, but gives tax credits for any prior taxes paid to foreign tax authorities. Exceptions to these general rules exist, and give rise to the (perfectly legal) tax avoidance industry. Among these exceptions is a policy which gives special tax status to firms or individuals who reside in one country, but who earn all their income abroad. This is perfectly consistent with the territorial principle, but the benefit is "ring-fenced" since it is not available to other tax-payers in the domestic market and does not

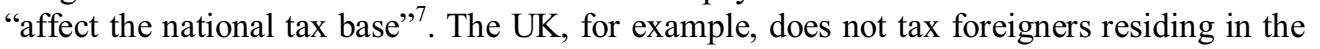
UK as long as all their income arises abroad, and many Swiss cantons negotiate the tax rate with wealthy foreign residents on condition that they earn nothing in Switzerland. So far, these practices have not caused international disputes, because no distortion of markets can be invoked. On the other hand, the United States for many years offered special tax advantages to domestic firms which earned over $95 \%$ of their income from exports (the socalled "Designated International Sales Corporation" or DISC). This was later amended to the "Foreign Sales Corporation", or FSC, as a result of a successful complaint from the EU that the DISC regime was in effect an export subsidy, forbidden under GATT rules. In 2000 the WTO Dispute Settlement Body judged the FSC regime to be distortionary, also because it offered an effective export subsidy. From an economic point of view, there is a clear distortion in the allocation of resources between products exported and similar products sold on the domestic market by the same firm.

\section{"Ring-Fenced" Holding Companies}

However, the OECD and EU are not after the Swiss and British schemes to attract wealthy foreign residents (or not yet), and are happy to leave the DISC/FSC problem to WTO. What they are really concerned about is ring-fenced international holding companies. These are well-known corporate devices which exist in order to hold shares in other companies, or to

6 See CURZON PRICE Victoria, "Industrial Policy" in El-Agraa (Ed.) The European Union, Economics and Policies, 7th edition, Financial Times and Prentice Hall, London etc. 2004, pp. 212237, for an account of forbidden state aids to industry in the European Union

${ }^{7}$ Conclusions of the ECOFIN Council Meeting on 1 December 1997 concerning taxation policy (98/C, OJ C 2/1 of 6 January 1998), Annex 1 "Code of conduct for business taxation".

${ }^{8}$ WTO Appellate Body Report, United States: Tax Treatment for "Foreign Sales Corporations", adopted by Disputes Settlement Body 20 March 2000. 
own patent or other rights which are then leased to "daughter" companies in return for a fee. Firms operating in many countries find it useful to concentrate their "holdings" in a single structure, especially if that structure is exempt from normal corporate tax. As far as the holding company's dividend income is concerned, this has usually been taxed at the "daughter" company level, so it is normal that dividends paid to "mother" should be tax exempt, or enjoy a lighter tax burden, and when the latter pays out dividends to the ultimate owner, incorporated in a high-tax country, these will be taxed according to the law of that state. However, it is frequently asserted that such holding companies are not transparent and may facilitate tax evasion through international transfer pricing, inflated service charges or exaggerated royalty payments. This may indeed be the case, but it is a long-established principle that one country does not enforce another's tax laws', so it is up to each sovereign state to enforce its own laws. In fact, most countries have very strict laws which allow tax authorities to bring declared inter-firm prices into line with market prices. This question is, however, different from whether a "ring-fenced" international holding company, by nature, distorts the international allocation of resources. The answer is not quite the same that as given earlier with regard to encouraging inward foreign direct investment with tax holidays. The international holding company attracts inward capital flows and encourages outward foreign investment. It concentrates capital on the inward flows, and then disperses it again on the outward flows. It provokes, on its own account, no inter-sectoral misallocation of resources, and therefore according to our standard cannot be considered "harmful".

No or Low Effective Tax Rates ${ }^{10}$

The OECD, in its first report on "Harmful tax competition", was unwise enough to claim that general, non-discriminatory, low or zero tax rates could be "harmful", if used in conjunction with other "harmful practices", such as ring-fencing, lack of transparency, or lack of information-sharing between tax authorities, if they shifted resources, and hence economic activity, away from high and towards low-tax countries ${ }^{11}$. This is close enough to saying that low taxes are "harmful" because they attract mobile productive resources from high-tax countries. But are mobile productive resources not fair game? As long as there is no intersectoral misallocation of resources, it cannot be a crime to attract them. Resources move to where their general over-all rate of return is the highest, and tax treatment is only part of the long list of variables which will be taken into consideration by investors. To say that low taxes are "harmful" because they shift mobile resources in their direction is much the same as saying that low wages in China are "harmful" because they shift resources, and hence economic activity, away from high-wage Europe to low-wage China. For sure, such things constitute competition, but it is not harmful competition, because it does not distort the allocation of resources. Thus, as far as wage differentials are concerned, China attracts resources into labour-intensive industries, while Europe attracts resources into capitalintensive sectors. Far from being inefficient, this shift of resources is generally considered to be positive and in line with comparativve advantage.

As for international tax differentials, as long as they are sectorally neutral, any investments which do occur because of them will presumably reflect the host country's underlying pattern of comparative advantage, and cannot be considered harmful or distortionary in any way. Generally low taxes, like market-friendly laws or an incorruptible judiciary, are part of the general factor endowments of a country, and will help to determine the over-all level of economic activity. This is sometimes called "absolute advantage", in contrast to comparative advantage, and intergovernmental competition in shaping absolute advantage is sometimes

\footnotetext{
${ }^{9}$ Richard TEATHER, The Benefits of Tax Competition, IEA, London, 2005, p. 83

${ }^{10}$ OECD "Harmful tax competition: an emerging global issue", Paris, 1998.

${ }^{11}$ Switzerland and Luxembourg refused to endorse the OECD's Report, inter alia, on the grounds that it described their laws allowing for "ring-fenced" low taxes and client confidentiality as being "harmful".
} 
referred to as institutional competition. Since it does not distort comparative advantage, nowhere is it condemned in international law.

Furthermore, unlike the climate, or natural resources, laws, including tax laws, are manmade and can be changed. Therefore the high tax country, if it wants to attract economic activity, and even retain such economic activity as it still has, is free to modify its policies, if it so desires. Conversely, it is not at all clear why the low tax country should alter its laws to suit the high tax state. Each country remains fully sovereign in this regard.

The OECD's definition of harmful tax competition in these terms is also almost naively transparent. If tax competition is deemed "harmful" when it is likely to shift resources, and hence economic activity, away from high and towards low-tax countries, the OECD is making the implicit claim that high-tax, big governments are somehow "better" than low-tax, small ones.

Another problem, in tax measures and its implication in tax competition and allocation of resources are transparency and exchange of information and how the tax evasion distorts the allocation.

Many "tax havens", which make a business of taking in the savings of residents of high tax countries and investing them in tax-free securities, have strict bank-secrecy laws and do not share any information with foreign tax authorities concerning their clients, unless the latter can show that they suspect criminal activity. They do not make easily available the identity of the beneficial owner of this or that account or shareholding (although they "know their customer" because they must be able to respond to a request for information from criminal investigations). According to the OECD, such countries "lack transparency" and are liable to be accused of harmful tax competition.

Thus the OECD supports the idea of information-sharing between tax authorities, on request, while the EU would like to instigate automatic, permanent and comprehensive information flows between tax authorities. Either would put an immediate stop to people accumulating savings in tax havens, and omitting to declare them to their own tax authorities. It is of course illegal not to declare assets and income held abroad, but the fact that some people are driven to this extreme suggests that in some countries taxes have reached unacceptably high levels. In exactly the same fashion, people are also driven to hide some of their economic activity from the tax man, giving rise to the well known phenomenon of the underground economy ${ }^{12}$. In fact, tax evasion is as old as taxes themselves, and the best way to minimize it is to levy reasonable taxes. International tax evasion and the local underground economy provide the two main escape routes. In modern democratic times, they also set implicit limits to the growth of government. They are both illegal, but the local shadow economy is now so widespread that governments know that they cannot enforce compliance without becoming hugely unpopular (suggesting that high taxes are, in fact, not as widely accepted by the population as some would like to think). Limiting international tax competition looks a much easier bet. However, if high-tax countries are successful in stopping the shift of savings to tax havens by enforcing transparency and information exchange, they will displace, but not halt, tax evasion and fiscal competition. The underground economy, both local and international, will grow. In the meantime, wealthy people and their assets will continue to move from high to low tax environments. Over time, the economically more attractive places will still enjoy much higher rates of economic growth. So are high-tax countries really better off without fiscal competition? Since full information sharing would put a stop to all international tax competition, it has become the main focus of both OECD and EU efforts in this area. The question which interests us, however, is whether tax evasion causes a distortion in the allocation of resources. The answer is surely no, for the same reasons outlined above. There is no inter-sectoral misallocation of resources. Savings are channelled to where returns are highest, almost never in the tax haven itself, which is just handling and collecting small streams of savings to form a great river of capital, which goes to whichever

${ }^{12}$ Council of the European Union, Joint Report on Employment 2004-2005, Brussels 9 March 2005. 
industry has successfully competed for it, wherever in the world that might be. In fact, tax havens perform a very useful job in this regard ${ }^{13}$.

\section{Conclusions}

I hope to has established that most international fiscal competition is beneficial rather than harmful, especially that type which is most severely criticized by the OECD and the EU lower direct taxes. This is because most tax regimes do not distort the international allocation of resources.

However, international fiscal competition is still in full swing and we have yet to see its full effects. For the moment, there is no "race to the bottom"14. Although direct taxes have fallen dramatically over the past 20 years, they are still well above zero. Furthermore, there has been no shift in the tax burden from capital to labour, but rather a shift from direct to indirect taxation. This trend is to be welcomed, because broad-based indirect taxes applying a standard rate to all goods and services are among the least distorting taxes one can devise. Total government revenues have increased, not fallen (as expected by the "race to the bottom" school), and in some cases have even increased as a proportion of GDP (though with expected negative effects on the rate of growth). This is a somewhat surprising result, given all the fuss about harmful tax competition. However, it suggests that fiscal competition still has some way to go.

\section{References}

1. CURZON PRICE Victoria (2004), The European Union, Economics and Policies, Financial Times and Prentice Hall, London, 7th edition

2. FELDSTEIN Martin, "Tax Avoidance and the Deadwight Loss of the Income Tax", Review of Economics and Statistics, November, 1999 calculates that for every dollar of extra tax revenue, the US economy loses two dollars of additional output.

3. HAYEK, F.A. (1960), The Constitution of Liberty, The University of Chicago Press, Chicago, 4. JANEBA, ECKHARD, WOLFGANG Peters, (1999), Tax evasion, tax competition and Gains from Nondiscrimination: The case of Interest taxation in Europe, Economic Journal, Issue 109, p. 93-109 5. LOCKWOOD Ben (1993), Commodity tax competition under destination and Origin Principles, Journal of Public Economies, Issue 52, p. 141-162

6. NORTH, Douglass C. (1981), Structure and Change in Economic History, Norton \& Co. New York \& London.

7. Council of the European Union Report (2005), Joint Report on Employment 2004-2005, Brussels.

8. OECD Report (1998), Harmful Tax Competition - An Emerging Global Issue, OECD.

\footnotetext{
${ }^{13}$ Richard TEATHER, op. cit. Chapter 6

${ }^{14}$ Germany has increased the VAT rate from 16 to $19 \%$ on 1 January 2007 , but is most unwisely also raising taxes on corporations and wealthy individuals. There is no "race to the bottom" here.
} 